\title{
Poly(aryl ether nitrile)s containing flexible side-chain-type quaternary phosphonium cations as anion exchange membranes
}

\author{
Chenyi Wang*, Zhengwang Tao, Xiaoyan Zhao, Jian Li and Qiang Ren
}

\begin{abstract}
In order to effectively improve the properties of anion exchange membrane (AEM) materials, a series of novel poly(aryl ether nitrile)s with flexible side-chain-type quaternary phosphonium cations (PAEN-TPP-x) were designed and prepared on the basis of considering the influences of polymer backbone, cationic group species and the connection way between the cations and polymer chains. The synthetic method, structure and ion-exchange capacity, water absorption, swelling, hydroxide conductivity and alkaline stability of the obtained AEMs were studied. A comparative study with other reported AEMs was also performed for further exploration of the relationship between the structure and properties. These AEMs with flexible side-chain-type quaternary phosphonium cations displayed good comprehensive properties. Their water uptakes and swelling ratios were in the range of $11.6 \%-22.7 \%$ and $4.4 \%-7.8 \%$ at $60^{\circ} \mathrm{C}$, respectively. They had hydroxide conductivity in the range of 28.6$45.8 \mathrm{mS} \mathrm{cm}^{-1}$ at $60^{\circ} \mathrm{C}$. Moreover, these AEMs also exhibited improved alkaline stability, and the hydroxide conductivity for PAEN-TPP- 0.35 could remain $82.1 \%$ and $80.6 \%$ of its initial value at 60 and $90^{\circ} \mathrm{C}$ in $2 \mathrm{~mol} \mathrm{~L}^{-1} \mathrm{NaOH}$ solution for $480 \mathrm{~h}$, respectively.
\end{abstract}

Keywords: anion exchange membrane, poly(aryl ether nitrile)s, quaternary phosphonium cations, alkaline stability

\section{INTRODUCTION}

With unsustainable development and environmental and climate issues brought about by burning fossil fuels, it is becoming more and more urgent to develop clean and efficient energy conversion and storage devices (such as fuel cells, flow batteries and lithium-ion batteries), which have become the focus of current research in new energy [1-5]. Among them, the fuel cells are a class of clean energy devices that directly convert the chemical energy stored in the fuel substance into electrical energy through the redox reaction without burning, which have the advantages of high energy conversion efficiency and low pollutant emission and have caused a lot of attention in the past few decades [6-8]. However, due to the high cost of commercial proton exchange membranes (PEMs), low electrode reactivity and heavy reliance on expensive rare Pt-based catalysts and high fuel purity requirements, large-scale application of PEM fuel cells (PEMFCs) has been greatly hindered [9]. In contrast, the cathode reaction kinetics of anion exchange membrane (AEM) fuel cells (AEMFCs) can be greatly enhanced due to the strongly alkaline environment, and nonprecious metal catalysts such as $\mathrm{Ni}, \mathrm{Co}, \mathrm{Fe}$ and $\mathrm{Mn}$-based catalysts can be used. Therefore, they are considered as a promising alternative to PEMFCs (especially in the field of portable/ fixed/standby power supplies) $[10,11]$.

As an important part of AEMFCs, AEMs are mainly used to separate the fuel/oxidant, conduct hydroxide ions $\left(\mathrm{OH}^{-}\right)$from the cathode to the anode, and diffuse water molecules from the anode to the cathode. AEMs consist of a polymer backbone and functional cations as well as mobile anions. In recent decades, the reported polymer backbone materials for AEMs mainly include polyolefin [12,13], polyvinyl alcohol [14], chitosan [15], poly(aryl ether)s [16-18], polyfluorene [19], polybenzimidazole [20], poly(aryleneimidazoliums) [21], poly(ether imide) [22], Tröger's base polymer [23,24], polyarylalkyl $[25,26]$, etc. Functional cations mainly include quaternary ammonium [27-29], imidazole [30,31], quaternary phosphonium [32,33], tertiary sulfonium [34], guanidine [35], metal-based cations [36,37], etc. Among the reported polymer backbone materials, poly(aryl ether nitrile)s

Jiangsu Collaborative Innovation Center of Photovoltaic Science and Engineering, Jiangsu Key Laboratory of Environmentally Friendly Polymeric Materials, School of Materials Science and Engineering, Changzhou University, Changzhou 213164, China

* Corresponding author (email: wangcy@cczu.edu.cn) 
(PAENs) impart good dimensional stability, mechanical properties and thermal stability to the matrix membrane due to the strong interaction among nitrile groups, and thus have been considered as an important class of AEM materials [17,38]. Among various functional cationic groups, it has been found that the quaternary phosphonium cations containing large volume groups have high alkali-resistance stability, and their large volume groups can effectively hinder the attack of $\mathrm{OH}^{-}$[39]. However, due to the limitations of structural design and synthetic methodology, the AEMs functionalized with quaternary phosphonium cations are much less reported than other cationic AEMs up to now.

The way in which the functional cations are combined with the polymer backbone is also one of the key factors affecting the properties of AEMs. Generally, the AEMs can be divided into "main-chain-type" and "side-chaintype" according to the connection between the functional ions and the polymer backbone. Among them, the "mainchain-type" means that the functional ions are attached to the polymer main chain directly or through a short chain $\left(-\mathrm{CH}_{2}-\right)$. AEMs of this type often exhibit high swelling ratio and low hydroxide conductivity due to the short $-\mathrm{CH}_{2}-$ limiting the free movement of functional ions, hindering the self-assembly of functional ions and the formation of continuous conductive channels [40]. In addition, they also have poor alkaline stability because the functional ionic groups are close to the main chain, and the functional ions and polymer skeleton would induce each other to promote degradation when attacked by hydroxide ions [41]. In contrast, in side-chain-type AEMs, the functional ions are attached to the polymer backbone through a longer side chain $\left(-\left(\mathrm{CH}_{2}\right)_{n}-, n>1\right)$. The long side chain increases the free movement of functional ions, which facilitates the self-assembly of the side chains and the formation of continuous conductive channels. So, the side-chain-type AEMs usually have moderate swelling rate and improved hydroxide conductivity in water [42]. At the same time, the long side chains weaken the interaction between the functional ions and the polymer backbone, and these membranes could exhibit higher alkaline stability $[43,44]$.

In order to effectively improve the hydroxide conductivity, alkaline stability and dimensional stability of the AEM materials, in this study, a series of novel PAENs with flexible side-chain-type quaternary phosphonium cations (PAEN-TPP- $x$ ) were designed and prepared on the basis of considering the influences of polymer backbone, cationic group species and the connection way between the cations and polymer chains in AEMs. The overall performance of the fabricated AEM materials would be further improved by simultaneously introducing "large volume quaternary phosphonium cations, flexible side chains and PAEN skeletons" into the polymer structures. The synthetic method, structure and ionexchange capacity (IEC), water absorption, swelling rate, hydroxide conductivity and alkaline stability of the obtained membranes were studied in detail. And a more indepth comparative study with other reported AEMs was also performed for further exploration of the relationship between the structure and properties. To the best of our knowledge, there are very few reports on PAENs containing flexible side-chain-type quaternary phosphonium ions for AEMs. This study aims to provide new ideas and methods for the design, preparation and modification of high performance polymer AEM materials.

\section{EXPERIMENTAL SECTION}

\section{Materials}

2,2-Bis(3-amino-4-hydroxyphenyl)hexafluoropropane (BABPAF, >98.0\%) and 2,6-difluorobenzonitrile (DFBN, $>99.0 \%$ ) were purchased from Tokyo Chemical Industry; 4,4'-biphenol (BP, >97.0\%) and N,N-diisopropylethylamine (DIPEA, >99\%) were purchased from Shanghai Aladdin Reagent Co. Ltd. (4-Bromobutyl)triphenylphosphonium bromide $\left(\mathrm{BrC}_{4} \mathrm{TPP},>98 \%\right)$ was purchased from J K Chemical. Other reagents and solvents are commercially available and used directly.

\section{Synthesis of amino-containing PAENs (PAEN-N-x)}

In the PAEN series copolymers, a synthetic process of PAEN-N-0.35 ( $x=0.35$ indicates the ratio of the amount of BABPAF to DFBN is 35/65) is taken as an example (Scheme 1): BABPAF $(1.9229 \mathrm{~g}, \quad 5.25 \mathrm{mmol}), \quad$ BP $(1.8155 \mathrm{~g}, 9.75 \mathrm{mmol})$, DFBN $(2.0865 \mathrm{~g}, 15.00 \mathrm{mmol})$, $\mathrm{K}_{2} \mathrm{CO}_{3} \quad(4.9756 \mathrm{~g}, 36.00 \mathrm{mmol}), \quad \mathrm{N}$-methylpyrrolidone (NMP) $(16.0 \mathrm{~mL})$ and toluene $(6 \mathrm{~mL})$ were sequentially added to a $100-\mathrm{mL}$ three-necked flask equipped with a mechanical stirrer, a water separator, a spherical condenser, and a nitrogen inlet. After being stirred for 30 min under a nitrogen atmosphere at $140-150^{\circ} \mathrm{C}$, the water in the system was removed by $\mathrm{N}_{2}$. Then the temperature was adjusted to $150-160^{\circ} \mathrm{C}$ and kept for $4-5 \mathrm{~h}$. When the viscosity of the system was too high, an appropriate amount of NMP was added to reduce the viscosity of the system. After being stirred uniformly, it was allowed to settle in deionized water to obtain a pale yellow filamentous product. The amino-containing copolymer (PAEN-N-0.35) was obtained by washing, 


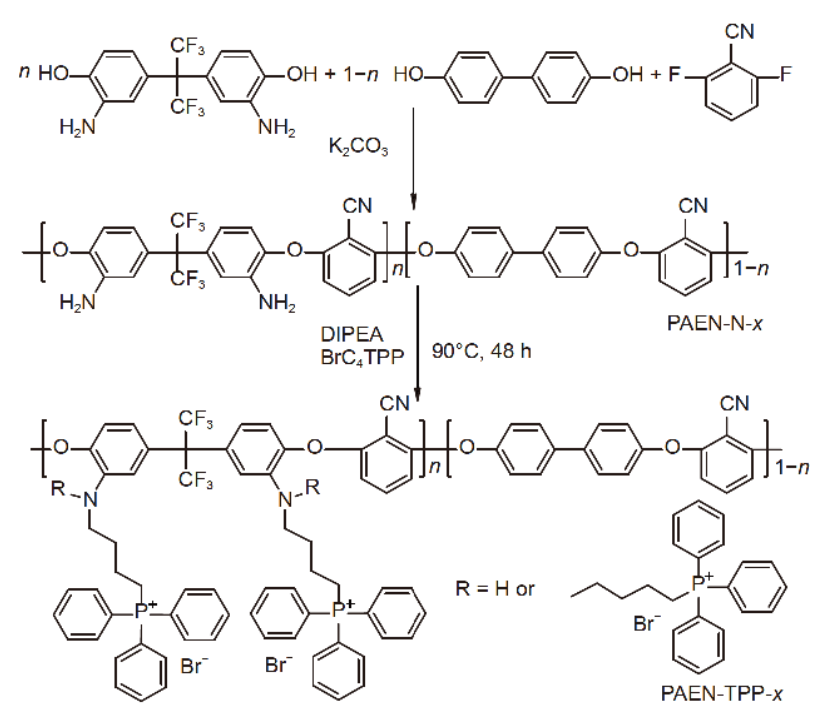

Scheme 1 Synthesis of the PAEN-N- $x$ and PAEN-TPP- $x$.

soaking and drying.

\section{Synthesis of PAEN-TPP- $x$}

In the PAEN-TPP- $x$ series, the synthetic process of PAEN-TPP-0.35 is taken as an example (Scheme 1): first, $1.0 \mathrm{~g}$ of PAEN-N-0.35 $\left(2.01 \mathrm{mmol}-\mathrm{NH}_{2}\right)$ and $30 \mathrm{~mL}$ of NMP were placed in a $100-\mathrm{mL}$ three-necked flask equipped with a mechanical stirrer, a spherical condenser, and a nitrogen inlet, and the polymer was sufficiently dissolved under heating. Then, after $2657 \mu \mathrm{L}$ (16.08 mmol) of DIPEA was added and the solution was stirred for $2 \mathrm{~h}$ at $60^{\circ} \mathrm{C}, 5.7661 \mathrm{~g}(12.06 \mathrm{mmol})$ of $\mathrm{BrC}_{4} \mathrm{TPP}$ was added. After reacting for $48 \mathrm{~h}$ under a nitrogen atmosphere at $90^{\circ} \mathrm{C}$, the mixture was slowly settled into $300 \mathrm{~mL}$ of isopropanol, filtered, washed with a large amount of ethanol, taken out and dried in a $90^{\circ} \mathrm{C}$ vacuum oven for $12 \mathrm{~h}$ to obtain the PAEN-TPP-0.35.

\section{Preparation of the membrane}

PAEN-TPP- $x(0.5 \mathrm{~g})$ was dissolved in $14 \mathrm{~mL}$ NMP, filtered through a $0.45-\mu \mathrm{m}$ teflon needle filter, poured into a $6 \mathrm{~cm} \times 6 \mathrm{~cm}$ glass mold, dried at $80^{\circ} \mathrm{C}$ for $24 \mathrm{~h}$, and then vacuum dried for another $24 \mathrm{~h}$. The anion membrane was peeled off, and immersed in $1 \mathrm{~mol} \mathrm{~L}^{-1} \mathrm{NaOH}$ solution for $24 \mathrm{~h}$, followed by immersion in deionized water for $24 \mathrm{~h}$ to remove the residual alkali to obtain a basic AEM PAEN-TPP- $x$. The thickness of the membrane was in the range of $40-50 \mu \mathrm{m}$.

\section{Characterization}

${ }^{1} \mathrm{H}$ NMR spectra of the PAEN-N- $x$ and PAEN-TPP- $x$ were obtained from a Bruker AVANCE DMX-400 NMR instrument at $400 \mathrm{MHz}$, using dimethyl sulfoxide (DMSO) $-\mathrm{d}_{6}$ as the solvent and tetramethylsilane (TMS) as an internal reference. The molecular weight of the PAEN$\mathrm{N}-x$ was determined via gel permeation chromatography (GPC) by using a Waters 515 HPLC pump, coupled with two Styragel columns (Waters HR4E and HR5E) and a Waters 2414 refractive index detector. Tetrahydrofuran (THF) was used as the eluent with a flow rate of $0.95 \mathrm{~mL} \mathrm{~min}^{-1}$ and polystyrene standards were used to calibrate the columns. The PAEN-N- $x(0.025 \mathrm{~g})$ was dissolved in $4 \mathrm{~mL}$ of THF, and filtered through a $0.45-\mu \mathrm{m}$ polytetrafluoroethylene needle filter, and the molecular weight and distribution of the polymer were tested at $35^{\circ} \mathrm{C}$.

IEC of the AEMs in $\mathrm{Cl}^{-}$form was determined by Mohr titration. First, the AEM samples were ion exchanged in aqueous $\mathrm{KCl}$ solution $\left(1 \mathrm{~mol} \mathrm{~L}^{-1}\right)$ for $24 \mathrm{~h}$ (during this time, the $\mathrm{KCl}$ solution was replaced every $4 \mathrm{~h}$ ) and then washed with deionized water thoroughly. Each AEM sample was dried at $80^{\circ} \mathrm{C}$ in vacuum for $24 \mathrm{~h}$ and weighed. Then each AEM sample $\left(\mathrm{Cl}^{-}\right.$form) was immersed in $40 \mathrm{~mL}$ of aqueous $\mathrm{NaNO}_{3}$ solution $\left(0.2 \mathrm{~mol} \mathrm{~L}^{-1}\right)$ for $12 \mathrm{~h}$. The combined $\mathrm{NaNO}_{3}$ solution was titrated with aqueous $\mathrm{AgNO}_{3}$ solution $\left(0.1 \mathrm{~mol} \mathrm{~L}^{-1}\right)$ by using $\mathrm{K}_{2} \mathrm{CrO}_{4}$ as an aS- 6 colorimetric indicator. The IEC was calculated by using

$\mathrm{IEC}=\frac{C_{\mathrm{AgNO}_{3}} V_{\mathrm{AgNO}_{3}}}{m_{\mathrm{dry}}}$,

where $C_{\mathrm{AgNO}_{3}}$ and $V_{\mathrm{AgNO}_{3}}$ are the concentration and volume of the $\mathrm{AgNO}_{3}$ solution, and $m_{\mathrm{dry}}$ is the dry mass of the AEM.

The IEC of AEMs can also be determined by ${ }^{1} \mathrm{H}$ NMR. First of all, the conversion rate $f$ of the $-\mathrm{NH}_{2}$ to $\mathrm{N}-\mathrm{C}$ was calculated by ${ }^{1} \mathrm{H}$ NMR based on the amount of $\mathrm{H}$ on the benzene ring of BABPAF, $f=1-S_{-\mathrm{NH}_{-}} / S_{-\mathrm{NH}_{2}}$, and then the IEC was calculated by using

$$
\mathrm{IEC}=\frac{4 \times x \times f \times 1000}{(465.35+334.40 \times 4 \times f) \times x+285.30 \times(1-x)},
$$

where $x$ represents the content of the repeating units with amino structure.

The water uptake (WU) and swelling ratio (SR) of the PAEN-TPP- $x$ copolymers were measured in the $\mathrm{Br}^{-}$form. First, a membrane of regular size $(1 \mathrm{~cm} \times 5 \mathrm{~cm})$ was immersed in deionized water at different temperatures for one day. The weight $\left(W_{\text {wet }}\right)$, length $\left(L_{\text {wet }}\right)$ and width $\left(W i_{\text {wet }}\right)$ of the wet sample were measured after the surface water was removed with tissue paper. Then, the membrane was dried at $80^{\circ} \mathrm{C}$ and the weight $\left(W_{\text {dry }}\right)$, length 
$\left(L_{\mathrm{dry}}\right)$ and width $\left(W i_{\mathrm{dry}}\right)$ of the dried sample were measured. $S=(L \times W i)^{1 / 2}$ indicates the size of the membranes. The WU and SR were calculated by using

$\mathrm{WU}=\frac{W_{\mathrm{wet}}-W_{\text {dry }}}{W_{\text {dry }}} \times 100 \%$,

$\mathrm{SR}=\frac{S_{\text {wet }}-S_{\text {dry }}}{S_{\text {dry }}} \times 100 \%$.

The hydration number $(\lambda)$ refers to the number of water molecules carried on a single quaternary phosphonium cation. It was calculated by using

$\lambda=\frac{\mathrm{WU} \times 10}{\mathrm{IEC} \times 18.02}$.

The hydroxide conductivity $(\sigma)$ of the AEM was tested by a GAMRY Referance 3000 electro-chemical workstation manufactured in the United States in a frequency range of 1 to $10^{5} \mathrm{~Hz}$ and a temperature range of 20 to $80^{\circ} \mathrm{C}$ by using a two-electrode method. It was calculated by using

$\sigma=\frac{d}{L \times W \times R}$,

where $d(\mathrm{~cm})$ is the distance between the two electrodes, $L(\mathrm{~cm})$ and $W(\mathrm{~cm})$ are the width and thickness of the membrane, respectively, and $R(\Omega)$ is the test resistance. And the average of three measurements was made to reduce the error.

Atomic force microscopy (AFM) investigation was performed with a digital instrument (DI) NanoScope III, using microfabricated cantilevers with a force constant of $20 \mathrm{~N} \mathrm{~m}^{-1}$.

The mechanical properties of the PAEN-TPP- $x$ membranes were measured at normal temperature under the condition of complete hydration by using the WDT-5 electronic universal testing machine produced by Shenzhen Kaiqiang Machinery Co. Ltd. (China). The membrane was cut into strips of $5 \mathrm{~cm} \times 1 \mathrm{~cm}$ by using scissors according to the test requirements, the tensile load was $5 \mathrm{kN}$ and the tensile rate was $5 \mathrm{~mm} \mathrm{~min}^{-1}$. And the average of three measurements was made to reduce the error.

The thermal gravimetric analysis (TGA) of the PAENTPP- $x$ membranes was carried out by using TG 209 F1 thermogravimetric manufactured by Netzsch, Germany. The temperature was raised from 50 to $800^{\circ} \mathrm{C}$ at a rate of $20^{\circ} \mathrm{C} \mathrm{min}^{-1}$ and the test was carried out under nitrogen atmosphere. The membrane was dried in a vacuum oven at $80^{\circ} \mathrm{C}$ for $6 \mathrm{~h}$ before testing.

The alkaline stability of the membrane was analyzed by measuring the IEC, hydroxide conductivities and ${ }^{1} \mathrm{H}$ NMR spectra of the membrane at different times. The
PAEN-TPP- $x$ membrane was cut into $6 \mathrm{~cm} \times 2 \mathrm{~cm}$ strips and placed in $2 \mathrm{~mol} \mathrm{~L}^{-1} \mathrm{NaOH}$ solution at 60 or $90^{\circ} \mathrm{C}$.

\section{RESULTS AND DISCUSSION}

\section{Synthesis and characterization of the copolymers}

A series of PAEN-N- $x$ were synthesized by aromatic nucleophilic substitution polycondensation reaction $\left(\mathrm{K}_{2} \mathrm{CO}_{3}\right.$ as the catalyst) and adjusting the ratio of $\mathrm{BAB}-$ $\mathrm{PAF}$ to BP. The mole percentage of amino groups in PAEN can be tuned by the feed ratio of BABPAF to BP, as shown in Scheme 1, thereby controlling the IEC of the membrane. The polymerization proceeded smoothly, a homogeneous solution was obtained, and no cross-linking occurred. The molecular weights of the copolymers were determined by GPC (Table 1). The number average molecular weights $\left(M_{\mathrm{n}}\right)$ of the obtained polymers ranged from $5.98 \times 10^{4}$ to $6.63 \times 10^{4} \mathrm{~g} \mathrm{~mol}^{-1}$, and the weight average molecular weights $\left(M_{\mathrm{w}}\right)$ were $12.68 \times 10^{4}$ to $15.45 \times$ $10^{4} \mathrm{~g} \mathrm{~mol}^{-1}$. The polydispersity indexes (PDIs) were between 2.12 and 2.33. These results indicate that the series of PAENs have high molecular weights and moderate molecular weight distributions.

The quaternary phosphonium ions were introduced into the PAEN-N- $x$ backbone by alkylation of the amino groups. Excess amount of DIPEA and quaternary ammonium cations with long aliphatic side chain and extended reaction time were used to ensure the conversion rate of ionized copolymer. The ${ }^{1} \mathrm{H}$ NMR spectra of PAEN-N-0.35 and PAEN-TPP-0.35 are shown in Fig. 1. The characteristic peak of the amine proton $\left(-\mathrm{NH}_{2}\right)$ in PAEN-N-0.35 appeared at $5.48 \mathrm{ppm}$, which confirmed the successful synthesis of the PAEN copolymers containing the amino groups. The residual solvent could not be removed by vacuum drying and its chemical shift occurred at 2.99, 2.69 and $1.21 \mathrm{ppm}$. The ${ }^{1} \mathrm{H}$ NMR spectrum of PAEN-TPP-0.35 showed a significant difference compared with PAEN-N-0.35. The peak of the $\left(-\mathrm{NH}_{2}\right)$ proton at $5.48 \mathrm{ppm}$ disappeared, and a secondary amine $(-\mathrm{NH}-)$ proton peak that did not react completely appeared at $5.85 \mathrm{ppm}$. Due to the influence of

Table 1 GPC analyses of the PAEN-N- $x$

\begin{tabular}{cccc}
\hline Copolymers & $M_{\mathrm{n}}\left(\times 10^{4} \mathrm{~g} \mathrm{~mol}^{-1}\right)$ & $M_{\mathrm{w}}\left(\times 10^{4} \mathrm{~g} \mathrm{~mol}^{-1}\right)$ & PDI \\
\hline PAEN-N-0.15 & 5.98 & 12.68 & 2.12 \\
PAEN-N-0.20 & 6.12 & 13.16 & 2.15 \\
PAEN-N-0.25 & 6.27 & 13.98 & 2.23 \\
PAEN-N-0.30 & 6.49 & 14.60 & 2.25 \\
PAEN-N-0.35 & 6.63 & 15.45 & 2.33 \\
\hline
\end{tabular}



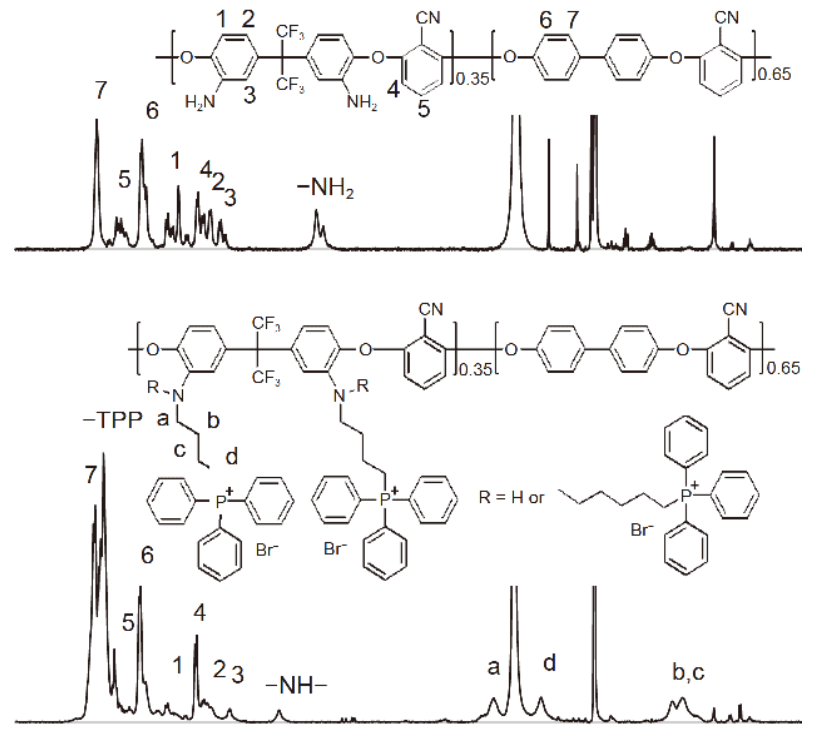

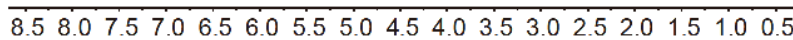
Chemical shift (ppm)

Figure $1{ }^{1} \mathrm{H}$ NMR spectra of PAEN-N-0.35 (top) and PAEN-TPP-0.35 (bottom).

steric hindrance, about $82 \%$ of $\mathrm{N}-\mathrm{H}$ was grafted with flexible side chain quaternary phosphonium ions, which can be calculated by the integral values of secondary and primary amino groups. In addition, the new peaks were assigned to the protons $\left(\mathrm{H}_{\mathrm{a}}, \mathrm{H}_{\mathrm{b}}, \mathrm{H}_{\mathrm{c}}, \mathrm{H}_{\mathrm{d}}\right)$ of the methylene group in the side chain, which appeared at 1.25 to $3.75 \mathrm{ppm}$. The characteristic peak of the cationic group
$\left(-\mathrm{P}^{+} \mathrm{Ph}_{3}\right)$ appeared at $7.65-7.79 \mathrm{ppm}$, which confirmed the successful synthesis of PAEN-TPP-0.35 with multiple flexible quaternary phosphonium ions in one repeat unit. The obtained ionic PAENs had good solubility in NMP, and a series of AEMs containing flexible side chain quaternary phosphonium could be obtained after solution casting.

\section{IEC, WU, SR and $\lambda$ of the PAEN-TPP- $x$}

$\mathrm{WU}$ is an important factor affecting the performance of fuel cell membranes. Water molecules in the membrane can promote the transport of hydroxide ions. However, swelling due to excessively high WU is not negligible because excessive swelling causes a decrease in the dimensional stability of the polymer membranes, and seriously lowers the mechanical strength of the membranes. The IECs of the PAEN-TPP- $x$ membranes are shown in Table 2. The IEC $\mathrm{NMR}_{\mathrm{NM}}$ values of the membranes calculated by the ratio of the area of the ${ }^{1} \mathrm{H}$ NMR spectra are between 1.02 and $1.56 \mathrm{mmol} \mathrm{g}^{-1}$. The IEC $_{\text {tit }}$ by the back titration measurement is similar to the IEC $_{\mathrm{NMR}}$, which is between 1.01 and $1.49 \mathrm{mmol} \mathrm{g}^{-1}$. The WU and SR of the PAEN-TPP- $x$ membranes are shown in Table 2 and Fig. 2a, b.

It can be seen from the graphs that the WU and SR of these membranes are consistent with those reported in other literatures, and both increase with the increase of IEC and temperature. Their WU and SR are in the range of $9.7 \%-19.0 \%$ and $3.6 \%-6.6 \%$ at $20^{\circ} \mathrm{C}$, respectively, while ranging in $11.6 \%-22.7 \%$ and $4.4 \%-7.8 \%$ at $60^{\circ} \mathrm{C}$, re-

Table 2 IEC, WU, SR and $\lambda$ of the PAEN-TPP- $x$ membranes and other quaternary phosphonium functionalized membranes

\begin{tabular}{|c|c|c|c|c|c|c|c|c|}
\hline \multirow{2}{*}{ Membrane } & \multicolumn{2}{|c|}{ IEC $\left(\mathrm{mmol} \mathrm{g}^{-1}\right)$} & \multicolumn{2}{|c|}{ WU (\%) } & \multicolumn{2}{|c|}{ SR (\%) } & \multirow{2}{*}{$\lambda^{\mathrm{c}}$} & \multirow{2}{*}{ Ref. } \\
\hline & IEC $_{\text {NMR }}{ }^{a}$ & $\mathrm{IEC}_{\mathrm{tit}}^{\mathrm{b}}$ & $20^{\circ} \mathrm{C}$ & $60^{\circ} \mathrm{C}$ & $20^{\circ} \mathrm{C}$ & $60^{\circ} \mathrm{C}$ & & \\
\hline PAEN-TPP-0.15 & 1.02 & 1.01 & 9.7 & 11.6 & 3.6 & 4.4 & 5.3 & This work \\
\hline PAEN-TPP- 0.20 & 1.20 & 1.19 & 12.8 & 15.2 & 4.6 & 5.5 & 6.0 & This work \\
\hline PAEN-TPP- 0.25 & 1.35 & 1.32 & 15.0 & 17.8 & 5.3 & 6.2 & 6.3 & This work \\
\hline PAEN-TPP- 0.30 & 1.46 & 1.43 & 16.9 & 20.4 & 5.9 & 7.1 & 6.5 & This work \\
\hline PAEN-TPP- 0.35 & 1.56 & 1.53 & 19.0 & 22.7 & 6.6 & 7.8 & 6.9 & This work \\
\hline PEEK-QPOH $126 \%$ & $1.26^{\mathrm{d}}$ & 1.19 & $\sim 180^{\mathrm{e}}$ & $\sim 400^{\mathrm{e}}$ & $38^{\mathrm{e}}$ & $60^{e}$ & 79.3 & {$[45]$} \\
\hline QPOH(80)PAES & 1.18 & 0.73 & 44.0 & 71.1 & 11.5 & 24.2 & 33.4 & {$[46]$} \\
\hline PPMPP-1 & - & 0.75 & $11.2^{\mathrm{f}}$ & - & $6.1^{\mathrm{f}}$ & - & 8.3 & {$[33]$} \\
\hline PРMPP-2 & - & 0.73 & $10.6^{\mathrm{f}}$ & - & $5.9^{\mathrm{f}}$ & - & 8.1 & [33] \\
\hline PPMPP-3 & - & 0.72 & $13.3^{\mathrm{f}}$ & - & $6.8^{\mathrm{f}}$ & - & 10.3 & [33] \\
\hline PPMPP-4 & - & 0.75 & $9.7^{f}$ & - & $5.7^{\mathrm{f}}$ & - & 7.2 & [33] \\
\hline TPP-30 & 0.99 & 0.95 & 13.9 & - & 3.0 & - & 7.8 & [47] \\
\hline LTPP-30 & 0.95 & 0.91 & 16.2 & - & 5.0 & - & 9.5 & [47] \\
\hline
\end{tabular}

a) Calculated from ${ }^{1} \mathrm{H}$ NMR spectrum; b) determined by Mohr titration at $20^{\circ} \mathrm{C}$; c) calculated at $20^{\circ} \mathrm{C} ; \mathrm{d}$ ) calculated by feed ratio; e) measured at $30^{\circ} \mathrm{C}$; f) measured at $25^{\circ} \mathrm{C}$. 

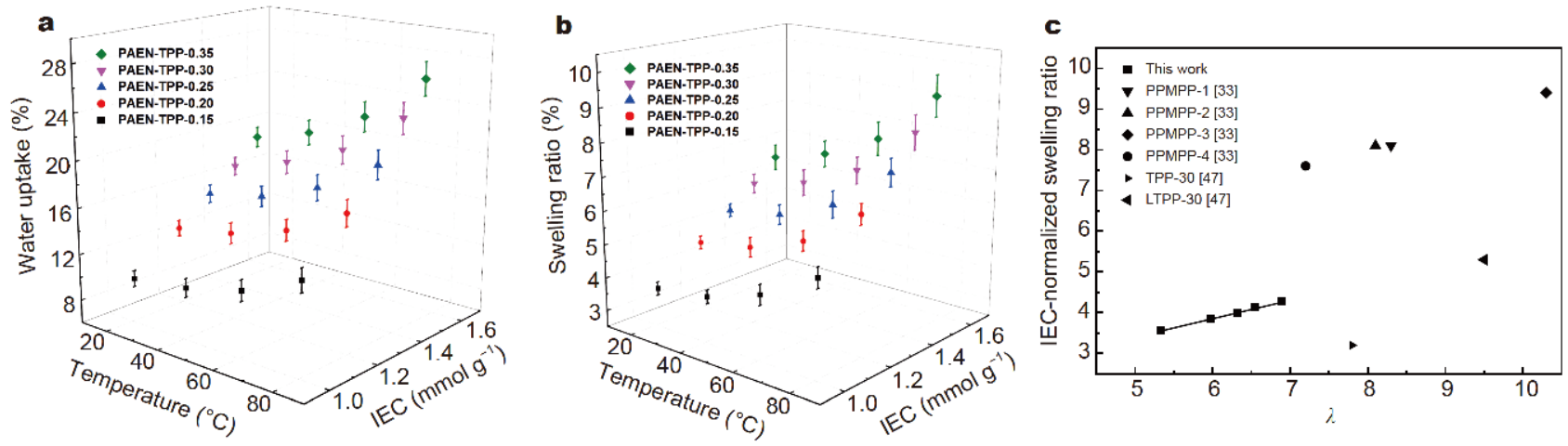

Figure 2 WU (a) and SR (b) of the PAEN-TPP- $x$ membranes, and (c) the IEC-normalized SR as a function of $\lambda$.

spectively. Besides, the $\lambda$ is between 5.3 and 6.9 at $20^{\circ} \mathrm{C}$. Compared with other quaternary phosphonium-functionalized AEMs, such as the main-chain-type tris $(2,4,6$ trimethoxyphenyl) phosphine functionalized poly(aryl ether ketone) membrane (PEEK-QPOH) [45], poly(aryl ether sulfone) membranes with rigid side chain quaternary phosphonium (QPOH(80)PAES) [46], and tetraphenylphosphonium-functionalized polyphosphazene membranes (PPMPP-1) [33], as well as poly(2,6-dimethyl phenylene oxide)s with clicked quaternary phosphonium groups (TPP-30 and LTPP-30) [47], the PAEN-TPP- $x$ membranes have lower or comparable WU and SR. In addition, the relationship between the IEC-normalized SR (SR/IEC) and $\lambda$ (Fig. 2c) shows that the IEC-normalized SR of the PAEN-TPP- $x$ membranes increases slowly with the increase of $\lambda$, and is lower than that of other structures of AEMs, showing good dimensional stability. This is mainly due to the strong interaction between the nitrile groups on the polymer backbone, and the resulting AEMs have their own anti-swelling properties, endowing these membranes with low WU and SR. In addition, the introduction of flexible alkyl groups enhances the selfassembly of hydrophilic ions and favors the swelling stability of the membrane.

\section{Hydroxide conductivity of PAEN-TPP- $x$}

The hydroxide conductivities $(\sigma)$ of the PAEN-TPP- $x$ membranes at different temperatures are shown in Fig. 3. Similar to the WU, the hydroxide conductivity of the PAEN-TPP- $x$ membranes increases with temperature or IEC. As the temperature increases, the diffusion rate of hydroxide in the membrane increases, and as the water absorption increases, the movement of the flexible quaternary phosphonium groups becomes more active. In addition, an increase in water content favors the local mobility of water, resulting in an increase in hydroxide conductivity. The PAEN-TPP- $x$ membranes exhibit high hydroxide conductivities in the range of $13.7-$ $23.8 \mathrm{mS} \mathrm{cm}^{-1}$ at $20^{\circ} \mathrm{C}$ and $28.6-45.8 \mathrm{mS} \mathrm{cm}^{-1}$ at $60^{\circ} \mathrm{C}$ (Table 3), respectively. Furthermore, from the Arrhenius equation: $E_{\mathrm{a}}=-k R$, where $k$ is the slope of the linear regression equation of $\ln (\sigma)-1000 / T$, and $R$ is the ideal gas constant of $8.314 \mathrm{~J} \mathrm{~mol}^{-1} \mathrm{~K}^{-1}$, the hydroxide conducting activation energy $E_{\mathrm{a}}$ of the membrane was calculated (Fig. 3c). The $E_{\mathrm{a}}$ is in the range of $13.78-15.25 \mathrm{~kJ} \mathrm{~mol}^{-1}$, which is opposite to the change trend of hydroxide conductivity. This indicates that the PAEN-TPP-0.35 membrane with the highest hydroxide conductivity has the lowest activation energy. That is, the energy required for $\mathrm{OH}^{-}$to pass through the ion channel within the AEM is less.

After the hydroxide conductivities of the membranes were normalized on the basis of the IEC ( $\sigma /$ IEC), all the membranes showed comparable IEC-normalized hydroxide conductivities ranging from 13.6 to 15.8 , and these values increased with $\lambda$ as shown in Fig. 3d. Moreover, these values are higher than those of some other AEMs, such as TPP-30 membrane [47] and PPMPP membrane [33]. However, LTPP-30 membranes with flexible side chains [47] have comparable values to the PAEN-TPP- $x$ membranes. The results show that higher IEC and higher $\lambda$ promote the transport of hydroxides, and the introduction of flexible side chains can effectively increase the hydroxide conductivity of the membrane.

\section{Thermal and mechanical properties}

Fuel cell applications require AEMs to have good mechanical properties. The mechanical properties of the PAEN-TPP- $x$ are listed in Table 3. The PAEN-TPP- $x$ membranes in the fully wet state have a tensile strength of 26.3-41.6 MPa and an elongation at break of 7.2\%-15.1\%. However, it should be mentioned that a membrane with a 

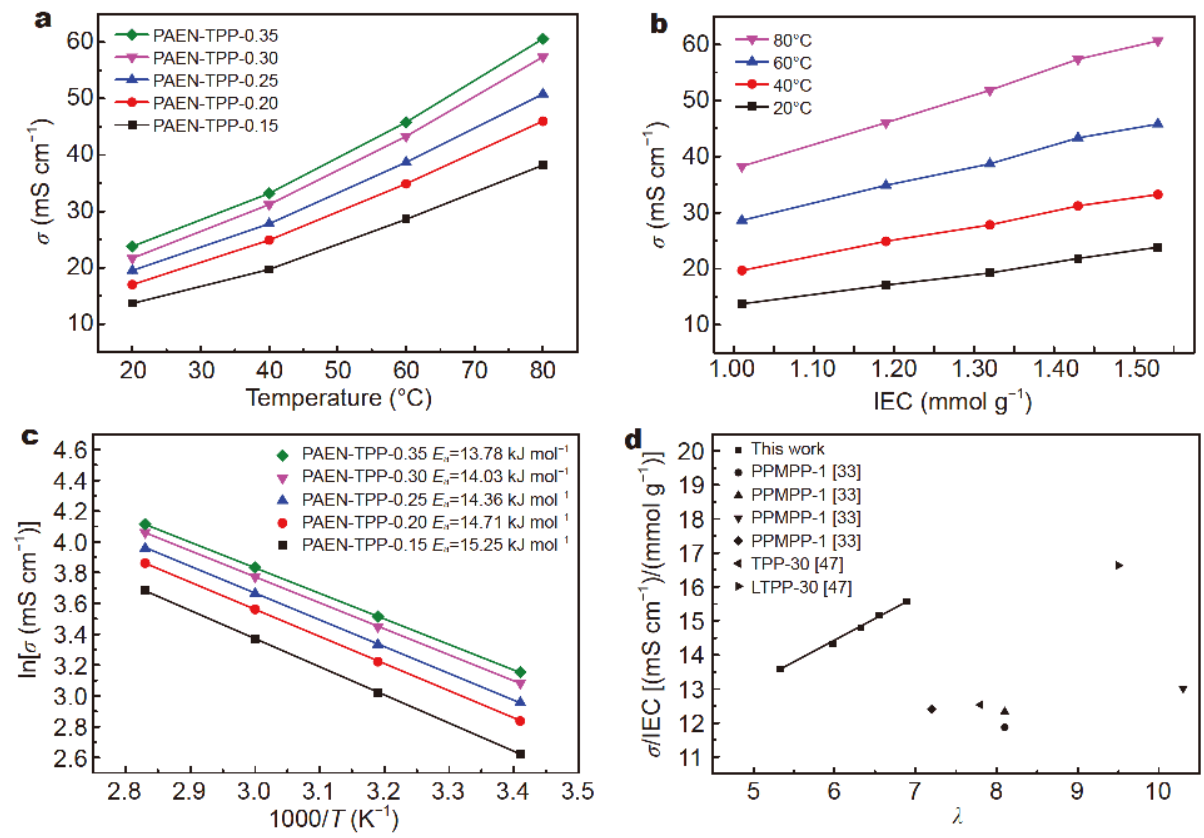

Figure 3 Hydroxide conductivity of the PAEN-TPP- $x$. Hydroxide conductivity as a function of (a) temperature and (b) IEC. (c) Arrhenius plots of the PAEN-TPP- $x$. (d) The IEC-normalized hydroxide conductivity of the PAEN-TPP- $x$ membranes as a function of $\lambda$.

Table 3 Hydroxide conductivities and mechanical properties of the PAEN-TPP- $x$ membranes (TS: tensile strength, TM: tensile modulus, EB: elongation at break)

\begin{tabular}{|c|c|c|c|c|c|c|c|}
\hline \multirow{2}{*}{ Membrane } & \multirow{2}{*}{ IEC $\left(\mathrm{mmol} \mathrm{g}^{-1}\right)$} & \multicolumn{2}{|c|}{$\sigma\left(\mathrm{mS} \mathrm{cm}^{-1}\right)$} & \multirow{2}{*}{$E_{\mathrm{a}}\left(\mathrm{kJ} \mathrm{mol}^{-1}\right)$} & \multirow{2}{*}{ TS (MPa) } & \multirow{2}{*}{$\mathrm{TM}(\mathrm{MPa})$} & \multirow{2}{*}{$\mathrm{EB}(\%)$} \\
\hline & & $20^{\circ} \mathrm{C}$ & $60^{\circ} \mathrm{C}$ & & & & \\
\hline PAEN-TPP-0.15 & 1.01 & 13.7 & 28.6 & 15.25 & 41.6 & 576.2 & 15.1 \\
\hline PAEN-TPP- 0.20 & 1.19 & 17.0 & 34.9 & 14.71 & 35.3 & 499.5 & 11.6 \\
\hline PAEN-TPP- 0.25 & 1.32 & 19.5 & 38.7 & 14.36 & 31.5 & 441.3 & 9.6 \\
\hline PAEN-TPP- 0.30 & 1.43 & 21.7 & 43.3 & 14.03 & 27.3 & 405.5 & 8.2 \\
\hline PAEN-TPP-0.35 & 1.53 & 23.8 & 45.8 & 13.78 & 24.7 & 372.9 & 7.2 \\
\hline
\end{tabular}

lower IEC exhibits superior mechanical properties compared with that having a higher IEC. It is believed that the poor compatibility between the PAEN polymer backbone and bulky quaternary phosphonium groups, as well as the water plasticization of polymer membrane reduces the tensile strength and elongation at break of the AEMs. Therefore, for high IEC membrane, lower tensile strength and elongation at break are observed.

The thermal properties of the representative PAEN-N0.35 and PAEN-TPP-0.35 ( $\mathrm{Br}^{-}$form) were tested by TGA. Fig. 4 shows the thermal weight loss curves of PAEN-N0.35 and PAEN-TPP-0.35 in $\mathrm{N}_{2}$ atmosphere. It can be seen that for PAEN-N-0.35, thermal decomposition occurs in three steps. The first step occurs at $132-266^{\circ} \mathrm{C}$, due to the degradation of the amino group; the second step at $318-510^{\circ} \mathrm{C}$ is related to the degradation of $-\mathrm{CF}_{3}$ and $-\mathrm{CN}$; and the third step occurs after $510^{\circ} \mathrm{C}$ due to the degradation of the PAEN backbone. As shown in Fig. 4, PAEN-TPP-0.35 also shows three degradation steps in addition to the slight weight loss before $150^{\circ} \mathrm{C}$ caused by evaporation of water absorbed in the membrane. The thermal decomposition in the range of $150-305^{\circ} \mathrm{C}$ is related to the decomposition of the alkyl side chain. The thermal decomposition between 305 and $510^{\circ} \mathrm{C}$ is related to the degradation of small molecules (such as triphenylphosphine) produced after alkylation; the weight loss after $510^{\circ} \mathrm{C}$ is due to the degradation of the PAEN skeleton. In general, the PAEN-TPP- $x$ has a good thermal stability and is suitable for operation in fuel cells.

\section{Membrane morphology and alkaline stability}

The hydrophobic backbone and hydrophilic cationic 


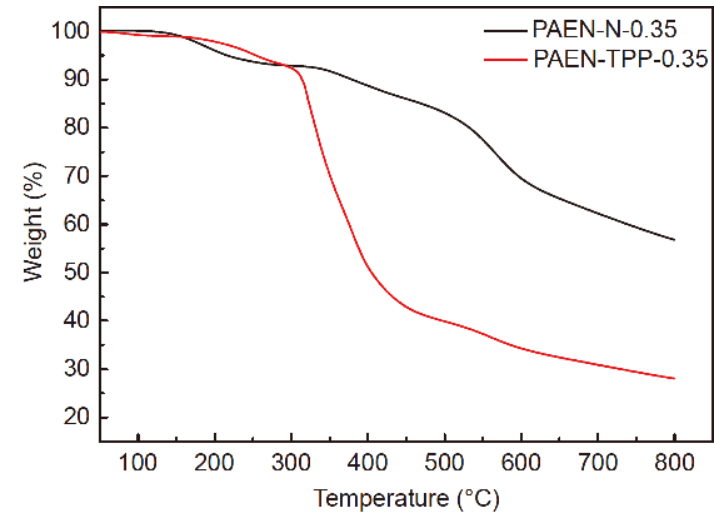

Figure 4 TGA plot of the PAEN-N-0.35 and PAEN-TPP-0.35 membranes.

groups in the copolymers would cause microphase separation within the membrane, which could create a communicating water channel for hydroxide conduction, thereby affecting the properties of the AEM. AFM was used to study the microstructure of the membrane and verify the microphase separation in the membrane. As can be seen from Fig. 5, the bright regions represent the hydrophobic domains formed by the polymer backbone and the dark regions represent the hydrophilic domains formed by the quaternary phosphonium ions. Clear ion clusters and hydrophilic domains of the PAEN-TPP- $x$ membranes can be readily observed. This can explain the ideal ion transport properties of a membrane having a particular chemical structure, with multiple quaternary phosphonium cationic groups on one repeating unit of the backbone increasing the local concentration of ionic groups, which promotes the formation of cationic clusters. The introduction of alkyl quaternary phosphonium ions increases the mobility and self-assembly of the hydrophilic moiety, showing a distinct dark hydrophilic channel in the AFM image.

Due to the Huffman elimination, $\mathrm{S}_{\mathrm{N}^{2}}$ nucleophilic substitution or formation of phosphonium salts, quaternary phosphonium ions could degrade under strong alkaline conditions, so the alkaline stability of AEM is usually widely concerned. The alkaline stability of PAENTPP- 0.35 was investigated in a $2 \mathrm{~mol} \mathrm{~L}^{-1} \mathrm{NaOH}$ solution at 60 and $90^{\circ} \mathrm{C}$, respectively. After a 480 -h durability test, the PAEN-TPP-0.35 membrane maintains its transparency and flexibility (Fig. 6a, b). The IEC and hydroxide conductivity changes of PAEN-TPP-0.3 were recorded after the stability test. As shown in Fig. 6c, the experimental IEC of PAEN-TPP- 0.35 gradually decreases with the immersion time. However, even in $2 \mathrm{~mol} \mathrm{~L}^{-1} \mathrm{NaOH}$ solution, the IEC of PAEN-TPP- 0.35 remained $83.7 \%$ and

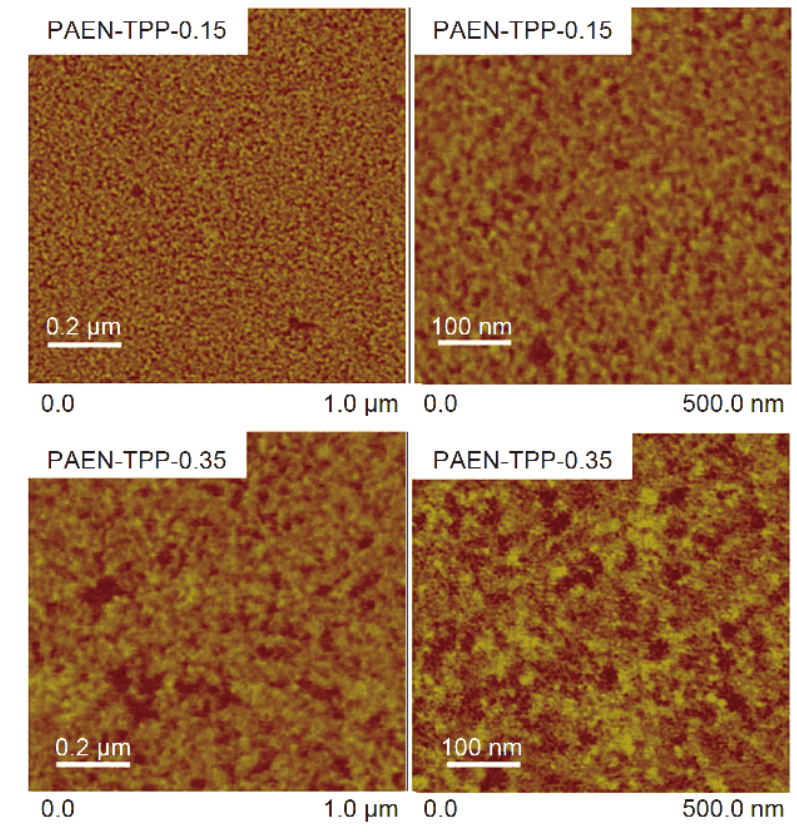

Figure 5 AFM image of PAEN-TPP-0.15 and PAEN-TPP-0.35.

$80.8 \%$ of its initial value at 60 and $90^{\circ} \mathrm{C}$, respectively. In addition, the hydroxide conductivity profile of the PAENTPP- 0.35 is shown in Fig. $6 \mathrm{~d}$ and it can remain $82.1 \%$ and $80.6 \%$ of its initial value at 60 and $90^{\circ} \mathrm{C}$, respectively. The results of IEC and hydroxide conductivity change show that the prepared AEM has better alkaline stability despite of a certain decrease.

To further observe the structural changes of the PAENTPP-0.35 during the alkali treatment, Fig. 6e shows the ${ }^{1} \mathrm{H}$ NMR spectra of the PAEN-TPP- 0.35 test sample before and after the alkali treatment. It can be seen that after the alkali treatment, no new peaks for the PAEN main chain cleavage appear in the ${ }^{1} \mathrm{H}$ NMR spectra in the low field. However, a new peak appears at $1.40 \mathrm{ppm}$, which may be the alkyl peak produced by the degradation of quaternary phosphonium ions. Changes in nuclear magnetic signals indicate that the main degradation pathway is nucleophilic substitution, and the decomposition of cationic groups is the main degradation pathway leading to lower IEC and conductivity.

According to the ${ }^{1} \mathrm{H}$ NMR analysis, PAEN-TPP- 0.35 has relatively obvious degradation after immersion for $480 \mathrm{~h}$ in strong alkali, which is consistent with the test results of IEC and ionic conductivity change. However, its alkaline stability is still improved compared with some AEM materials reported recently (Table 4). For example, the phenyl-linked triphenyl quaternary phosphoniumfunctionalized polyphosphazene membrane (PPMPP-1, 

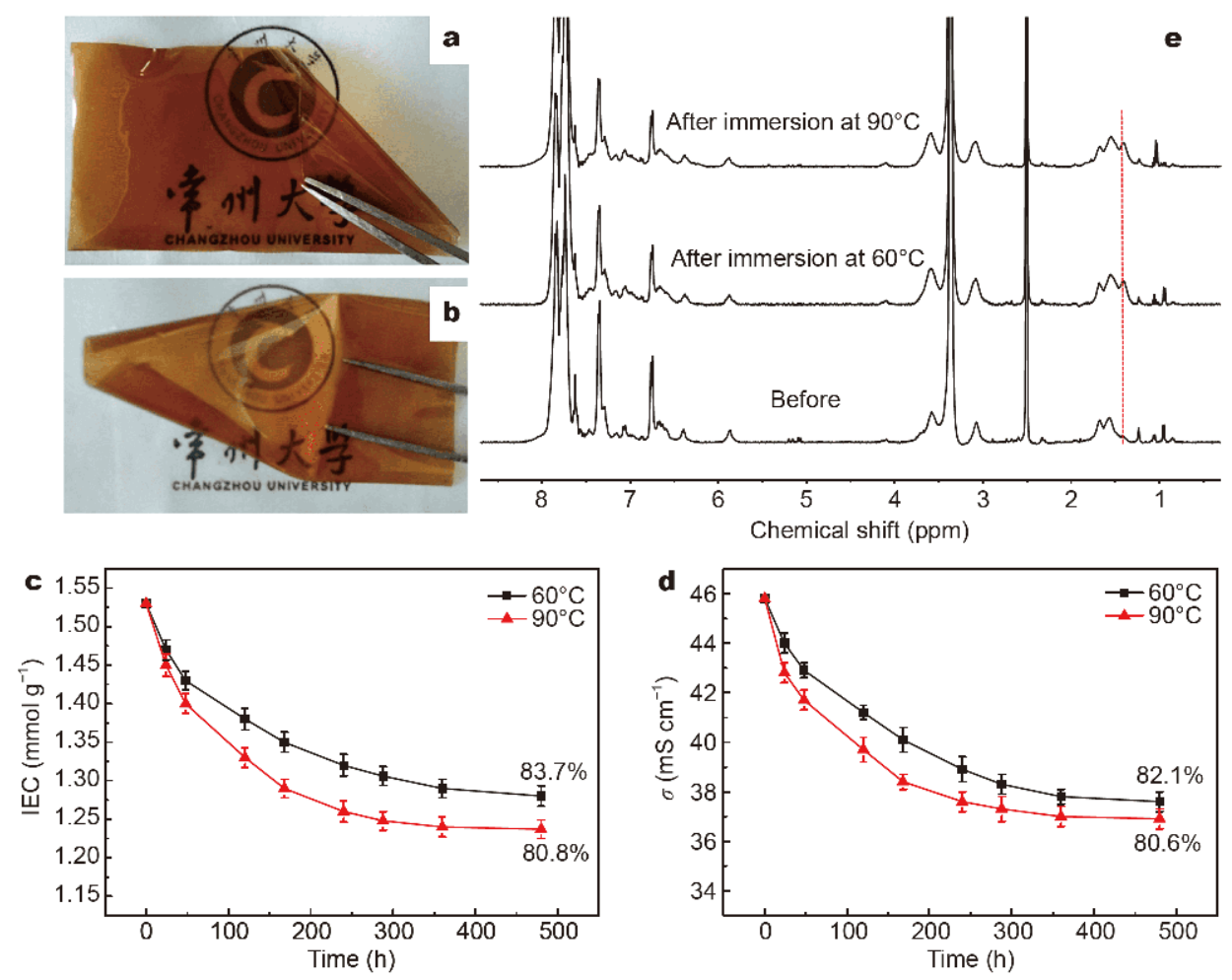

Figure 6 Alkaline stability of the PAEN-TPP-0.35. Appearance photos before (a) and after (b) immersion in $2 \mathrm{~mol} \mathrm{~L}^{-1} \mathrm{NaOH}$ solution at $90^{\circ} \mathrm{C}$ for $480 \mathrm{~h}$. The changing trend in IEC (b) and hydroxide conductivity (c) of PAEN-TPP- 0.35 after immersion in $2 \mathrm{~mol} \mathrm{~L}^{-1} \mathrm{NaOH}^{-1}$ solution at 60 or $90^{\circ} \mathrm{C}$ for $480 \mathrm{~h}$. (e) ${ }^{1} \mathrm{H}$ NMR spectra of PAEN-TPP-0.35 in DMSO-d $\mathrm{d}_{6}$ before and after alkaline stability tests in $2 \mathrm{~mol} \mathrm{~L}^{-1} \mathrm{NaOH}$ for $480 \mathrm{~h}$.

IEC $=0.75 \mathrm{mmol} \mathrm{g}^{-1}$ ) had $78 \%$ conduction retention in $1.0 \mathrm{~mol} \mathrm{~L}^{-1} \mathrm{KOH}$ solution at $60^{\circ} \mathrm{C}$ for $240 \mathrm{~h} \mathrm{[33];} \mathrm{the}$ trimethyl quaternary phosphonium-functionalized

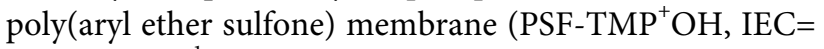
$0.97 \mathrm{mmol} \mathrm{g}^{-1}$ ) had $38 \%$ conduction retention in $1.0 \mathrm{~mol} \mathrm{~L}^{-1} \mathrm{KOH}$ solution at room temperature (RT) for $24 \mathrm{~h} \mathrm{[48];} \mathrm{and} \mathrm{a} \mathrm{flexible} \mathrm{alkylimidazolium-functionalized}$ side-chain type hyperbranched poly(aryl ether sulfone) AEM (BPES-4-Im, IEC $=1.80 \mathrm{mmol} \mathrm{g}^{-1}$ ) just had $70 \%$ conduction retention in $1.0 \mathrm{~mol} \mathrm{~L}^{-1} \mathrm{KOH}$ solution at

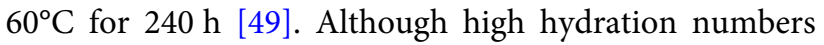

can reduce the attack of hydroxide ions [50], the obtained AEMs with low $\lambda$ still show good alkaline stability. The possible reason for the improved alkaline stability of PAEN-TPP- 0.35 is that the presence of the nitrile groups in the polymer main chain increases the interaction between the hydrophobic polymer skeleton, enhances the hydrophobicity of the polymer backbone of AEM membrane, and avoids the attack of the arylether linkages by $\mathrm{OH}^{-}$. In addition, the introduction of the alkyl side chains weakens the interaction between the main chain benzene ring and the quaternary phosphonium ions, and to some

Table 4 Alkaline stabilities of some recently reported membranes

\begin{tabular}{|c|c|c|c|c|c|c|c|}
\hline Membrane & Main chain & Cation & Linking group & IEC & Test conditions & Retention & Ref. \\
\hline PAEN-TPP-0.35 & PAEN & TPP & $-\mathrm{NHC}_{4}{ }_{-}^{-}$ & 1.22 & $\begin{array}{l}2 \mathrm{~mol} \mathrm{~L}^{-1} \mathrm{NaOH}, 60^{\circ} \mathrm{C}, 480 \mathrm{~h} \\
2 \mathrm{~mol} \mathrm{~L}^{-1} \mathrm{NaOH}, 90^{\circ} \mathrm{C}, 480 \mathrm{~h}\end{array}$ & $\begin{array}{l}82.1 \% \\
80.6 \%\end{array}$ & This work \\
\hline PPMPP-1 & \multirow{2}{*}{ PPZ } & TPP & $-\mathrm{Ph}-$ & 0.75 & $1 \mathrm{~mol} \mathrm{~L}^{-1} \mathrm{KOH}, 60^{\circ} \mathrm{C}, 240 \mathrm{~h}$ & $78 \%$ & [33] \\
\hline PPMPP-3 & & $\mathrm{TPP}\left(\mathrm{OCH}_{3}\right)_{3}$ & $-\mathrm{Ph}-$ & 0.72 & $1 \mathrm{~mol} \mathrm{~L}^{-1} \mathrm{KOH}, 60^{\circ} \mathrm{C}, 240 \mathrm{~h}$ & $92.4 \%$ & {$[33]$} \\
\hline TPP-30 & \multirow{2}{*}{$\mathrm{PPO}$} & \multirow{2}{*}{$\mathrm{TPP}\left(\mathrm{OCH}_{3}\right)_{9}$} & $-\mathrm{N}_{3} \mathrm{C}-$ & 0.95 & $10 \mathrm{~mol} \mathrm{~L}^{-1} \mathrm{NaOH}, 80^{\circ} \mathrm{C}, 200 \mathrm{~h}$ & \multirow{2}{*}{$\sim 90 \%$} & [47] \\
\hline LTPP-30 & & & $-\mathrm{N}_{3} \mathrm{C}_{4-}$ & 0.91 & $10 \mathrm{~mol} \mathrm{~L}^{-1} \mathrm{NaOH}, 80^{\circ} \mathrm{C}, 200 \mathrm{~h}$ & & [47] \\
\hline PSF-TMP ${ }^{+} \mathrm{OH}$ & PSF & TMP & $-\mathrm{CH}_{2}-$ & 0.97 & $1 \mathrm{~mol} \mathrm{~L}^{-1} \mathrm{KOH}, \mathrm{RT}, 24 \mathrm{~h}$ & $\sim 38 \%$ & [48] \\
\hline BPES-4-Im & PES & $\operatorname{Im}$ & $-\mathrm{C}_{4^{-}}$ & 1.80 & $1 \mathrm{~mol} \mathrm{~L}^{-1} \mathrm{KOH}, 60^{\circ} \mathrm{C}, 240 \mathrm{~h}$ & $\sim 70 \%$ & [49] \\
\hline
\end{tabular}


extent protects the quaternary phosphonium ion from attack by $\mathrm{OH}^{-}$.

\section{CONCLUSIONS}

A series of novel PAENs with flexible side-chain-type quaternary phosphonium cations were designed and prepared as AEMs by a convenient synthetic route. Compared with some other reported AEMs containing quaternary phosphonium cations, these AEMs showed superior properties. They had moderate WU and lower SR. Meanwhile, these AEMs had comparable or higher hydroxide conductivity at lower hydration number. Moreover, they also exhibited obviously improved alkaline stability, and the hydroxide conductivity for PAENTPP- 0.35 could remain $80.6 \%$ after $480 \mathrm{~h}$ in $2 \mathrm{~mol} \mathrm{~L}^{-1}$ $\mathrm{NaOH}$ solution at $90^{\circ} \mathrm{C}$. The simultaneous incorporation of "large volume quaternary phosphonium cations, flexible side chains and PAEN skeletons" in polymer structures plays a key role in improving the properties of the obtained AEMs. This study provides a new idea and method for the design, preparation and modification of high-performance polymer AEM materials.

Received 20 October 2019; accepted 20 November 2019; published online 20 December 2019

1 Miyake J, Kusakabe M, Tsutsumida A, et al. Remarkable reinforcement effect in sulfonated aromatic polymers as fuel cell membrane. ACS Appl Energy Mater, 2018, 1: 1233-1238

2 Zhang J, He Y, Liang X, et al. Towards the gemini cation anion exchange membranes by nucleophilic substitution reaction. Sci China Mater, 2019, 62: 973-981

3 Chen Y, Liu Z, Lin M, et al. Selectivity enhancement of quaternized poly(arylene ether ketone) membranes by ion segregation for vanadium redox flow batteries. Sci China Chem, 2019, 62: 479-490

4 Zhang S, Zhang B, Chen Y, et al. Preparation and properties of quaternized poly(phthalazinone ether ketone ketone) anion-exchange membrane for all-vanadium redox flow battery. Chin Sci Bull, 2019, 64: 187-193

5 Chen Y, Lin Q, Zheng Y, et al. Densely quaternized anion exchange membranes synthesized from Ullmann coupling extension of ionic segments for vanadium redox flow batteries. Sci China Mater, 2019, 62: 211-224

6 Wang C, Zhou Y, Shen B, et al. Proton-conducting poly(ether sulfone ketone)s containing a high density of pendant sulfonic groups by a convenient and mild post-sulfonation. Polym Chem, 2018, 9: 4984-4993

7 Wang C, Shen B, Zhou Y, et al. Sulfonated aromatic polyamides containing nitrile groups as proton exchange fuel cell membranes. Int J Hydrogen Energy, 2015, 40: 6422-6429

8 Zhang X, Chu X, Zhang M, et al. Molecularly designed, solvent processable tetraalkylammonium-functionalized fluoropolyolefin for durable anion exchange membrane fuel cells. J Membrane Sci, 2019, 574: 212-221

9 Wang C, Zhou Y, Xu C, et al. Synthesis and properties of new sidechain-type poly(arylene ether sulfone)s containing tri-imidazole cations as anion-exchange membranes. Int J Hydrogen Energy, 2018, 43: 20739-20749

10 Hossain $\mathrm{MM}$, Wu L, Liang $\mathrm{X}$, et al. Anion exchange membrane crosslinked in the easiest way stands out for fuel cells. J Power Sources, 2018, 390: 234-241

11 Kwasny MT, Zhu L, Hickner MA, et al. Thermodynamics of counterion release is critical for anion exchange membrane conductivity. J Am Chem Soc, 2018, 140: 7961-7969

12 Mandal M, Huang G, Kohl PA. Highly conductive anion-exchange membranes based on cross-linked poly(norbornene): Vinyl addition polymerization. ACS Appl Energy Mater, 2019, 2: 2447-2457

13 Liu L, Chu X, Li N. Recent development in polyolefin-based anion exchange membrane for fuel cell application. Chin Sci Bull, 2019, 64: $123-133$

14 Zheng XY, Song SY, Yang JR, et al. 4-Formyl dibenzo-18-crown-6 grafted polyvinyl alcohol as anion exchange membranes for fuel cell. Eur Polym J, 2019, 112: 581-590

15 Ryu J, Seo JY, Choi BN, et al. Quaternized chitosan-based anion exchange membrane for alkaline direct methanol fuel cells. J Industrial Eng Chem, 2019, 73: 254-259

16 Lim H, Lee B, Yun D, et al. Poly(2,6-dimethyl-1,4-phenylene oxide)s with various head groups: Effect of head groups on the properties of anion exchange membranes. ACS Appl Mater Interfaces, 2018, 10: 41279-41292

17 Xing Y, Liu L, Wang C, et al. Side-chain-type anion exchange membranes for vanadium flow battery: Properties and degradation mechanism. J Mater Chem A, 2018, 6: 22778-22789

18 Zhang Z, Xiao X, Yan X, et al. Highly conductive anion exchange membranes based on one-step benzylation modification of poly(ether ether ketone). J Membrane Sci, 2019, 574: 205-211

19 Lee WH, Mohanty AD, Bae C. Fluorene-based hydroxide ion conducting polymers for chemically stable anion exchange membrane fuel cells. ACS Macro Lett, 2015, 4: 453-457

20 Sana B, Das A, Jana T. Polybenzimidazole as alkaline anion exchange membrane with twin hydroxide ion conducting sites. Polymer, 2019, 172: 213-220

21 Fan J, Wright AG, Britton B, et al. Cationic polyelectrolytes, stable in $10 \mathrm{M} \mathrm{KOH}_{\mathrm{aq}}$ at $100^{\circ} \mathrm{C}$. ACS Macro Lett, 2017, 6: 1089-1093

22 Oh BH, Kim AR, Yoo DJ. Profile of extended chemical stability and mechanical integrity and high hydroxide ion conductivity of poly(ether imide) based membranes for anion exchange membrane fuel cells. Int J Hydrogen Energy, 2019, 44: 4281-4292

23 Yang Z, Guo R, Malpass-Evans R, et al. Highly conductive anionexchange membranes from microporous Tröger's base polymers. Angew Chem Int Ed, 2016, 55: 11499-11502

$24 \mathrm{Hu} \mathrm{C}$, Zhang Q, Lin C, et al. Multi-cation crosslinked anion exchange membranes from microporous Tröger's base copolymers. J Mater Chem A, 2018, 6: 13302-13311

25 Akiyama R, Yokota N, Miyatake K. Chemically stable, highly anion conductive polymers composed of quinquephenylene and pendant ammonium groups. Macromolecules, 2019, 52: 2131-2138

26 Olsson JS, Pham TH, Jannasch P. Tuning poly(arylene piperidinium) anion-exchange membranes by copolymerization, partial quaternization and crosslinking. J Membrane Sci, 2019, 578: 183-195

27 Wang C, Shen B, Xu C, et al. Side-chain-type poly(arylene ether sulfone)s containing multiple quaternary ammonium groups as anion exchange membranes. J Membrane Sci, 2015, 492: 281-288

28 Zhao C, Bu F, Na H. Preparation and properties of anion exchange membranes based on multiple quaternary ammonium groups. Chin Sci Bull, 2019, 64: 172-179 

membered $\mathrm{N}$-cyclic quaternary ammonium cations in advanced anion exchange membranes for fuel cells: Synthesis and durability. J Membrane Sci, 2019, 578: 239-250

$30 \mathrm{Hu}$ M, Ding L, Shehzad MA, et al. Comb-shaped anion exchange membrane with densely grafted short chains or loosely grafted long chains? J Membrane Sci, 2019, 585: 150-156

31 Wang $\mathrm{C}, \mathrm{Xu} \mathrm{C}$, Shen B, et al. Stable poly(arylene ether sulfone)s anion exchange membranes containing imidazolium cations on pendant phenyl rings. Electrochim Acta, 2016, 190: 1057-1065

32 Liu Y, Zhang B, Kinsinger CL, et al. Anion exchange membranes composed of a poly(2,6-dimethyl-1,4-phenylene oxide) random copolymer functionalized with a bulky phosphonium cation. J Membrane Sci, 2016, 506: 50-59

33 Han H, Ma H, Yu J, et al. Preparation and performance of novel tetraphenylphosphonium-functionalized polyphosphazene membranes for alkaline fuel cells. Eur Polym J, 2019, 114: 109-117

34 Jang H, Hossain MA, Sutradhar SC, et al. Anion conductive tetrasulfonium hydroxides poly(fluorenylene ether sulfone) membrane for fuel cell application. Int J Hydrogen Energy, 2017, 42: 12759-12767

35 Xue B, Wang F, Zheng J, et al. Highly stable polysulfone anion exchange membranes incorporated with bulky alkyl substituted guanidinium cations. Mol Syst Des Eng, 2019, 4: 1039-1047

36 Zhu T, Xu S, Rahman A, et al. Cationic metallo-polyelectrolytes for robust alkaline anion-exchange membranes. Angew Chem Int Ed, 2018, 57: 2388-2392

$37 \mathrm{Gu} \mathrm{S}$, Wang J, Kaspar RB, et al. Permethyl cobaltocenium $\left(\mathrm{Cp}_{2}^{*} \mathrm{Co}^{+}\right)$as an ultra-stable cation for polymer hydroxide-exchange membranes. Sci Rep, 2015, 5: 11668

38 Gao L, Wu X, Yan X, et al. Alkali stability of anion exchange membrane. Chin Sci Bull, 2019, 64: 145-152

$39 \mathrm{Gu} \mathrm{S}$, Cai R, Luo T, et al. A soluble and highly conductive ionomer for high-performance hydroxide exchange membrane fuel cells. Angew Chem Int Ed, 2009, 48: 6499-6502

40 Akiyama R, Yokota N, Otsuji K, et al. Structurally well-defined anion conductive aromatic copolymers: Effect of the side-chain length. Macromolecules, 2018, 51: 3394-3404

41 Arges CG, Zhang L. Anion exchange membranes' evolution toward high hydroxide ion conductivity and alkaline resiliency. ACS Appl Energy Mater, 2018, 1: 2991-3012

42 Shin DW, Guiver MD, Lee YM. Hydrocarbon-based polymer electrolyte membranes: Importance of morphology on ion transport and membrane stability. Chem Rev, 2017, 117: 4759-4805

43 Dang HS, Jannasch P. Exploring different cationic alkyl side chain designs for enhanced alkaline stability and hydroxide ion conductivity of anion-exchange membranes. Macromolecules, 2015, 48: 5742-5751

44 Zheng J, Zhang Q, Qian H, et al. Self-assembly prepared anion exchange membranes with high alkaline stability and organic solvent resistance. J Membrane Sci, 2017, 522: 159-167

45 Yan X, Gu S, He G, et al. Quaternary phosphonium-functionalized poly(ether ether ketone) as highly conductive and alkali-stable hydroxide exchange membrane for fuel cells. J Membrane Sci, 2014, 466: 220-228

46 Papakonstantinou P, Deimede V. Self-cross-linked quaternary phosphonium based anion exchange membranes: Assessing the influence of quaternary phosphonium groups on alkaline stability. RSC Adv, 2016, 6: 114329-114343

47 Tang $\mathrm{H}, \mathrm{Li} \mathrm{D}, \mathrm{Li} \mathrm{N}$, et al. Anion conductive poly(2,6-dimethyl phenylene oxide)s with clicked bulky quaternary phosphonium groups. J Membrane Sci, 2018, 558: 9-16

48 Arges CG, Parrondo J, Johnson G, et al. Assessing the influence of different cation chemistries on ionic conductivity and alkaline stability of anion exchange membranes. J Mater Chem, 2012, 22: 3733-3744

49 Fang M, Liu D, Neelakandan S, et al. Side-chain effects on the properties of highly branched imidazolium-functionalized copolymer anion exchange membranes. Appl Surf Sci, 2019, 493: 1306-1316

50 Gottesfeld S, Dekel DR, Page M, et al. Anion exchange membrane fuel cells: Current status and remaining challenges. J Power Sources, 2018, 375: 170-184

Acknowledgements This work was supported by the National Natural Science Foundation of China (21404016), the Key Research Program of Jiangsu Province (BE2017645), the Six Talent Peaks Project of Jiangsu Province (XCL-078), and a project funded by the Priority Academic Program Development of Jiangsu Higher Education Institutions of China.

Author contributions Wang $\mathrm{C}$ designed the experiments, Tao $\mathrm{Z}$ performed the experiments, Wang $\mathrm{C}$ and Tao $\mathrm{Z}$ analyzed the data and wrote the paper. All authors contributed to the general discussion.

Conflict of interest The authors declare that they have no conflict of interest.

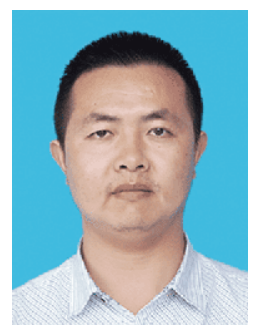

Chenyi Wang is an associate professor at the School of Materials Science and Engineering, Changzhou University. He obtained his $\mathrm{PhD}$ from Donghua University in 2010. After that, he went to Hanyang University (The Republic of Korea, 2010-2012) as a postdoctoral fellow. His research involves the development of high-performance polymeric materials for fuel cells, flow batteries, and microelectronics devices.

\section{含柔性侧链季鏻阳离子结构的聚芳醚腈阴离子交 换膜}

汪称意, 陶正旺, 赵晓燕, 李坚, 任强

摘要 为有效改善聚合物阴离子交换膜材料(AEMs)的性能, 本研 究在综合考虑聚合物结构、离子官能团种类及其链接方式对 AEMs 影响的基础上，设计制备了一系列含有柔性侧链型季鏻阳离 子结构的新型聚芳醚腈(PAEN-TPP- $x$ ) 阴离子交换膜. 分别对所制 聚芳醚腈阴离子交换膜的合成方法、结构和离子交换容量、吸水 率、溶胀率、氢氧化物电导率及碱稳定性进行了系统研究, 并与 一些其他已报道的AEMs进行了比较研究, 以进一步探索其结构与 性能之间的关系. 研究发现所制备的含有柔性侧链型季鏻阳离子 结构的聚芳醚腈阴离子交换膜具有良好的综合性能. 在 $60^{\circ} \mathrm{C}$ 下, 它 们的吸水率、溶胀率和离子传导率分别为 $11.6 \%-22.7 \%, 4.4 \%-$ $7.8 \%$ 和 28.6-45.8 $\mathrm{mS} \mathrm{cm} \mathrm{cm}^{-1}$. 与此同时, 该类AEMs还表现出良好的 碱性稳定性, 其中代表性样品PAEN-TPP-0.35在 $2 \mathrm{~mol} \mathrm{~L}^{-1} \mathrm{NaOH}$ 溶 液中、 60 和 $90^{\circ} \mathrm{C}$ 下浸泡 $480 \mathrm{~h}$ 后的 $\mathrm{OH}^{-}$传导率分别保持在其初始值 的 $82.1 \%$ 和 $80.6 \%$. 本研究可为高性能聚合物阴离子交换膜材料的 设计制备和改性提供新的思路和方法. 